Article

\title{
Predicting Lake Eutrophication Responses to Multiple Scenarios of Lake Restoration: A Three-Dimensional Modeling Approach
}

\author{
Yanping Wang ${ }^{1,2,3}$, Weiping Hu ${ }^{1, *}$, Zhaoliang Peng ${ }^{1}$, Ye Zeng ${ }^{1,2}$ and Karsten Rinke ${ }^{3}$ (D) \\ 1 State Key Laboratory of Lake Science and Environment, Nanjing Institute of Geography and Limnology, \\ Chinese Academy of Sciences, 73 East Beijing Road, Nanjing 210008, China; wyp9107@163.com (Y.W.); \\ zlpeng@niglas.ac.cn (Z.P.); marcochen94@hotmail.com (Y.Z.) \\ 2 University of Chinese Academy of Sciences, Beijing 100049, China \\ 3 Helmholtz Centre for Environmental Research, Department of Lake Research, Brückstraße 3 a, Magdeburg \\ 39114, Germany; karsten.rinke@ufz.de \\ * Correspondence: wphu@niglas.ac.cn; Tel.: +86-25-8688-2180; Fax: +86-25-5771-4759
}

Received: 14 June 2018; Accepted: 24 July 2018; Published: 27 July 2018

check for updates

\begin{abstract}
To improve the water quality and alleviate the eutrophication of Lake Yangchenghu, the third largest freshwater body within the Lake Taihu basin in China and an important source of drinking water, nutrient reduction strategies should be urgently addressed by decision makers, since virtually no improvement of water quality has taken place since the mid-1990s. Due to the lack of sufficient observation data and simulation results, a vertically compressed three-dimensional numerical model, the EcoTaihu model, was used to study the impact of three restoration measures on the water quality - namely, total nitrogen (TN), total phosphorus (TP) and biomass of phytoplankton (BP) —of Lake Yangchenghu: (i) total nutrient reduction, (ii) intensification of flushing by water transfer, and (iii) spatial adjustment of inflow channels. In particular, the spatial effects of the three restoration measures on the water quality were investigated. The results showed that the EcoTaihu model is applicable to other shallow lakes in China. The water quality responses to the different restoration scenarios showed significant spatio-temporal differences. The reduction of nutrient loads from inflows appeared to be the most effective measure for controlling the eutrophication and algal blooms in Lake Yangchenghu. The effectiveness of water transfer on the improvement of water quality for TN and TP was more influenced by the differences of nutrient concentrations between the transferred water and lake water, rather than flow rate, since no proportionate increase of improvement was observable in the case of larger transferred rates $\left(60 \mathrm{~m}^{3} \mathrm{~s}^{-1}\right)$. The spatial narrowing of inflowing rivers in the southwestern lake could preferentially improve the water quality in the southern bay of the western lake, but would also result in a deterioration trend of water quality in the total lake and drinking water abstraction areas.
\end{abstract}

Keywords: eutrophication responses; Eco Taihu model; scenario analysis; Lake Yangchenghu

\section{Introduction}

Lake eutrophication is one of the major global water pollution problems, which is caused by the excessive loading of nutrients, mainly nitrogen $(\mathrm{N})$ and phosphorus $(\mathrm{P})$, into the water bodies [1-3]. Excess nutrient loadings lead to the rapid production of phytoplankton and corresponding deterioration of water quality. In the worst case, algae blooms will break out and a reliable supply of drinking water is threatened. Therefore, urgent and effective engineering measures are required to prevent and control eutrophication [4]. The $\mathrm{N}$ and $\mathrm{P}$ available in the lake water can be decreased by reducing import, increasing retention in the sediment, or increasing export. Restoration 
measures for eutrophication control can be classified into two groups: (i) external measures aiming at reducing the load from catchment area, specifically including reduction of nutrient loads $[5,6]$ and flushing [7-9], whereas (ii) in-lake measures influence the properties within the lake, including chemical precipitation [10-12], sediment capping [13], sediment dredging [14,15], biological uptake [16], or bio-manipulation [17]. In-lake nutrient inactive measures, like chemical precipitation and sediment capping, were successfully performed in many lakes, but a long-term success can only be obtained with sufficiently reduced external P-loadings [10]. The reduction of nutrient loads is, therefore, the preferred measure for eutrophication control and efficient reduction of chlorophyll-a [18,19] as well as cyanobacterial biomass [20]. Intensifying flushing by additional water transfer is an alternative approach, which aims at increasing the $\mathrm{N}$ and $\mathrm{P}$ export of the lake by replacing the nutrient-rich lake water with nutrient-poor transferred water. The efficiency of improvement depends on the lake size and the details of the water transfers, with respect to water transfer volumes, timing, and other factors $[8,21]$. Considering the significant differences of the effects from these measures, and the difficulties in each implementation, it is essential to assess the effectiveness of certain measures for developing effective restoration strategies of a specific lake.

Urgent decisions for lake restorations have to be made for Lake Yangchenghu, which is used for drinking water supply, irrigation, fishing, and recreation. The water quality of Lake Yangchenghu is in a bad status, evaluated as Grade IV or even Grade V by the Chinese Environmental Water Quality Standards for Surface Water (GB3838-2002) all through the year. It suffers especially from eutrophication, resulting from excess external nutrient loads, as well as from internal loads. The efforts on nutrients control and eutrophication restoration for Lake Yangchenghu began in the middle and late 1990s [22], when the water quality of the lake was considered as eutrophic. Afterwards, the management committee of Lake Yangchenghu was set up in 1992, and the water quality protection ordinance of Lake Yangchenghu was issued by the People's Congress of Suzhou Municipality in 1996. Meanwhile, the area of net-enclosed crab aquaculture was cut down from $53.35 \mathrm{~km}^{2}$ to $21.33 \mathrm{~km}^{2}$ by the administrative department between 2002 and 2007. Moreover, all aquaculture farming was expected to close by the end of 2017 in order to reduce $\mathrm{N}$ and P concentrations. Nevertheless, the water quality of Lake Yangchenghu has still not achieved the expected water quality goals of Grade III [23,24]. It is noteworthy that the surrounding area of Lake Yangchenghu has experienced considerable economic development. The discharge of N, P, and chemical oxygen demand (COD) into the lake has been constantly increasing [25-27]. The water quality of the main influents is always poor, having been evaluated as Grade V, TP concentrations are at Grade V $\left(0.10-0.40 \mathrm{mg} \mathrm{L}^{-1}\right)$ or worse and have shown a further increasing trend in recent years [28]. Additionally, the total loads of inflows corresponded to a mean concentration of $17.34 \mathrm{~g} \mathrm{TN} \mathrm{m}^{-2} \mathrm{y}^{-1}$ and $1.39 \mathrm{~g} \mathrm{TP} \mathrm{m}^{-2} \mathrm{y}^{-1}$ from June 2015 to May 2016 (Table 1), which were around ten times the dangerous value, according to the loads standard value [29], and five times the internal loading calculated by the modeled release rates (Table 1). As a whole, Lake Yangchenghu acts as a net nutrient sink with an annually averaged positive retention of $63 \% \mathrm{TN}$ and 32\% TP from June 2015 to May 2016 (Table 1). Particularly, Lake Yangchenghu is also a highly flushed lake, with short retention times (0.38 year, Table 1$)$. These figures indicate that eutrophication is a serious problem in this lake and that external loads play an essential role. 
Table 1. The morphological, hydrological, and chemical characteristics of Lake Yangchenghu.

\begin{tabular}{|c|c|}
\hline Criterion & Parameter Value \\
\hline Lake surface $\left(\mathrm{km}^{2}\right)$ & 117 \\
\hline Mean depth (m) & 2.43 \\
\hline Volume $\left(10^{8} \mathrm{~m}^{3}\right)$ & 2.36 \\
\hline Discharge $\left(10^{8} \mathrm{~m}^{3} \mathrm{y}^{1}\right)$ & 6.14 \\
\hline Water residence time (year) & $0.38^{\text {a }}$ (June 2015-May 2016) \\
\hline External TN loading $\left(\mathrm{g} \mathrm{N} \mathrm{m}^{-2} \mathrm{y}^{-1}\right)$ & $17.34^{\mathrm{a}}(-)$ \\
\hline External TP loading $\left(\mathrm{g} \mathrm{P} \mathrm{m}^{-2} \mathrm{y}^{-1}\right)$ & $1.39^{\mathrm{a}}(-)$ \\
\hline Internal total $\mathrm{NH}_{4}{ }^{+}-\mathrm{N}$ loading $\left(\mathrm{g} \mathrm{N} \mathrm{m}^{-2} \mathrm{y}^{-1}\right)$ & $3.29^{\mathrm{a}}(-)$ \\
\hline Internal TP loading $\left(\mathrm{g} \mathrm{P} \mathrm{m}^{-2} \mathrm{y}^{-1}\right)$ & $0.26^{\mathrm{a}}(-)$ \\
\hline TN retention $(\%) *$ & $63^{a}(-)$ \\
\hline TP retention $(\%) *$ & $32^{\mathrm{a}}(-)$ \\
\hline Mean organic matter $\left(\mathrm{mg} \mathrm{L}^{-1}\right)$ & $6.94^{\mathrm{a}}\left(\right.$ February 2016); 5.38 (January 2009) $^{\mathrm{b}}$ \\
\hline Mean total suspended solids (mg L ${ }^{-1}$ ) & $14.20^{\mathrm{a}}$ (March 2016) \\
\hline Annual averaged $\mathrm{pH}$ & $7.47^{\mathrm{a}}(-)$ \\
\hline
\end{tabular}

${ }^{*}$ Retention $(\%)=\left(\right.$ total loads input-total loads output)/total loads input ${ }^{*} 100$. (一) means the same with upper contents. Data source: ${ }^{a}$, this study; ${ }^{b}$, Song et al. [30].

Models are useful tools for scientific research and lake management [31,32]. In the past decades, a number of dynamics models, such as Finite Volume Community Ocean Model (FVCOM) [33,34], Environmental Fluid Dynamics Code (EFDC) [35-39], Western Lake Erie Ecosystem Model (WLEEM) [20], PCLake [40,41], AQUATOX [42,43], Water Quality Analysis Simulation Program (WASP) [19,44], Eutrophication Ecosystem Model (EEM) [45], or Simulation by means of an Analytical Lake Model (SALMO) [46] have been developed and applied in quantifying the water quality responses to external loading, restoration efforts, and future decision making. Such models help to understand the responses of lake ecosystems to nutrient loads reduction and water transfer, and provide quantitative assessment of the eutrophication status. For example, Liu et al. [39] suggested that watershed nutrient loading had the greatest effect on the water quality of Lake Dianchi among the three driving forces: watershed nutrient loading, variations in transferred inflow water, and water level fluctuations. Hu et al. [47] indicated that water diversion could have a clear improvement on the Chl-a concentration in Lake Taihu. Apparently, the efficiency and costs of different lake management or restoration measures should be assessed using modeling before implementation.

In the present study, an application of the EcoTaihu model was used to assess the alternative management measures of eutrophication control in Lake Yangchenghu. EcoTaihu is a three-dimensional hydrodynamic and water quality model that has been successfully used to simulate water quality dynamics [48,49], forecast algae blooms, evaluate self-purification capacity [50], and assess the effects of water transfer [47]. The main objectives of this paper were to: (i) recalibrate the EcoTaihu model with the field data sets collected in Lake Yangchenghu; (ii) investigate the influences of three kinds of external measures (reduction of total nutrient loads, flushing by water transfer, and spatial adjustment of inflow tributaries) on water quality variables; (iii) derive recommendations for effective eutrophication control measures in drinking water abstraction areas as well as for the whole of Lake Yangchenghu.

\section{Methods}

\subsection{Study Area}

Lake Yangchenghu $\left(31^{\circ} 21^{\prime}-31^{\circ} 30^{\prime} \mathrm{N}, 120^{\circ} 39^{\prime}-120^{\circ} 51^{\prime} \mathrm{E}\right)$, the third largest freshwater lake in the basin of Lake Taihu is located in Suzhou, China (Figure 1, Table 1). The lake consists of a western part with water depths of around 1.7 to $2.5 \mathrm{~m}$, and a central and eastern part with water depths of around 1.5 to $3.0 \mathrm{~m}$. The lake volume is $2.36 \times 10^{8} \mathrm{~m}^{3}$, and the mean depth is $2.43 \mathrm{~m}$. It receives nutrient-rich discharges from the rivers in the west and northwest, and most outflows are located in the east and southeast of the lake. The concentration of mean organic matter in February 2016 was higher than the 
mean value in January 2009 [30]. The lake water was weak alkaline over the entire year. Among the inflows, the Baidang, Litanghe, Jimintang, and Shengtanggang rivers (Figure 1) contribute more than $80 \%$ of the total yearly inflow volume, and the Baidang River contribute about $33 \%$ of water volume and $45 \%$ of nutrient loads from inflow rivers. In the northeastern part of the lake, the Qipu River is used for water transfer from the Yangtze River to Lake Yangchenghu. The spatial location of inflows and outflows usually induces a west-to-east current in the lake, and shows a slightly worse water quality in the western lake than the central and eastern lake [23].

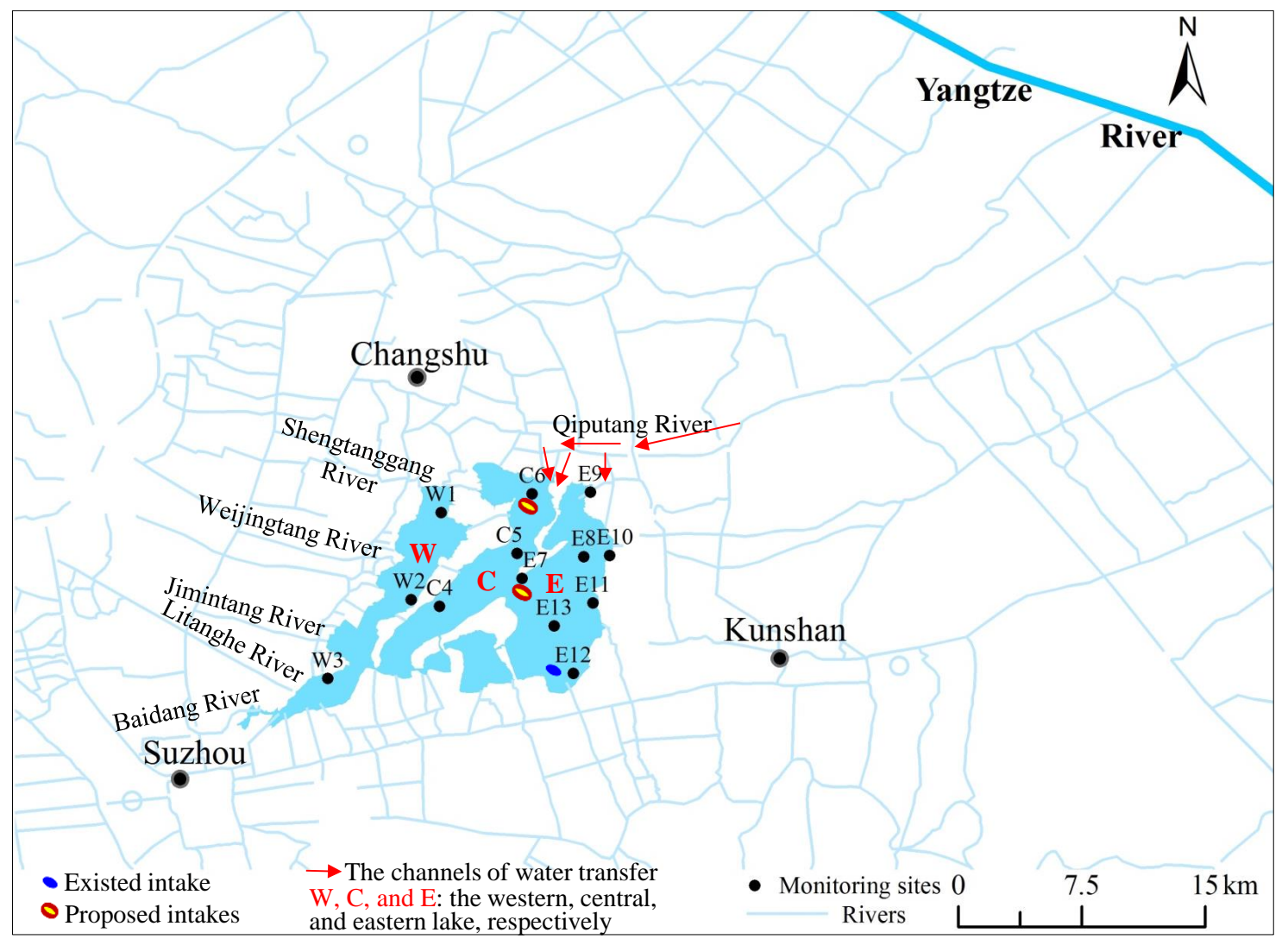

Figure 1. Location and measurement sites of Lake Yangchenghu.

\subsection{Water Sample and Meteorological Data Collection}

Water samples from the thirteen sites in lake water, inflows and outflows were collected monthly from June 2015 to May 2016. W1-W3 locates in the western lake, C4-C6 locates in the central lake, and E8-E13 locates in the eastern lake (Figure 1). Two liters of mixed water samples at $10 \mathrm{~cm}, 30 \mathrm{~cm}$, and $50 \mathrm{~cm}$ below the water surface at each site were collected by a polyethylene water sampler and stored at $4{ }^{\circ} \mathrm{C}$ before being analyzed for nutrients in the laboratory. Seven out of these thirteen sites were selected for the measurement of dissolved oxygen (DO) and the analysis of chlorophyll a (Chl-a). A $200 \mathrm{ml}$ complete mixture of the water samples from the different water layers at the seven sites selected was filtered through GF/C glass fiber filters ( $\varnothing 1.2 \mu \mathrm{m}$, Whatman, Amersham, UK). The filters were then used to determine $\mathrm{Chl}$-a level, which represents phytoplankton biomass. The Chl-a on the filters were extracted with hot ethanol [51], and determined using a spectrofluorophotometer under the wavelength of $665 \mathrm{~nm}$ and $750 \mathrm{~nm}$ (RF-5301PC, Shimadzu Corporation, Kyoto, Japan). The raw water samples and the water samples of the thirteen sites were used to determine the concentrations of TN and TP. Prior to the measurement of TN and TP, the quantitative volume of raw water from the different sampling sites was digested using potassium persulfate. The concentrations of TN and TP were measured according to the method provided by Jin and Tu [52]. Dissolved oxygen (DO) 
was monitored in situ at the seven sampling sites selected using a water quality sonde (YSI-6600V2, Yellow Spring Instruments, OH, USA). The boundary conditions for the model were taken as follows: input and output discharge of tributaries were monitored in situ with portable flow meter (SonTek, RiverSurveyor M9, SonTek, San Diego, CA, USA) monthly, and then linearly interpolated into daily data. Meteorological time series, including wind velocity and direction, precipitation, evaporation, and radiation data, were obtained from the meteorological stations in the vicinity of Lake Yangchenghu.

\subsection{Model Description}

EcoTaihu is a vertically compressed, three-dimensional, structural dynamic model, in which some eco-physiological functions can provide forecast to changes in the ecosystem structure $[31,53,54]$. The EcoTaihu model successfully couple hydrodynamics, nutrient cycling, and food chain networks into one coherent framework $[48,49]$. The model comprises three main modules and several sub-modules [48,55]. The first module is a relatively independent hydrological module. The second one is a food chain network module, including fish, zooplankton, organic detritus, algae, and aquatic macrophytes. The third one is the material transform and transport module, including dissolved oxygen, nitrogen, and phosphorus transport. The structure of the model is schematically depicted in Figure 2. Specifically, the initial field mainly includes the initial nutrient concentrations and the external input conditions at the beginning of the calculation. The boundary conditions indicate the inflows and outflows location, the variance of the lake water surface, and the friction between the sediment and the lake water at the bottom layer. External functions include inflow and outflow water discharge, nutrient loadings, precipitation, evaporation, wind speed, and wind directions, and so on. Parameter set denotes the setting of the coefficients and parameters in the hydrodynamic equations and material transportation equations; the parameters used in EcoTaihu model are in Appendix Table 1. Data assimilation denotes the input data substitution by the data of the next time step. An earlier version of EcoTaihu model was tested against measurements of TP, TN, DO, Chl-a, ammonia nitrogen $\left(\mathrm{NH}_{4}{ }^{+}-\mathrm{N}\right)$, nitrate nitrogen $\left(\mathrm{NO}_{3}{ }^{-}-\mathrm{N}\right)$, and phosphate phosphorus $\left(\mathrm{PO}_{4}{ }^{3-}-\mathrm{P}\right)$ from monitoring results of 33 sampling sites in Lake Taihu and showed a good agreement with the observations [48]. Then, it was expanded to include carbon cycling in the lake, and the output showed that the lake water was a source of atmospheric carbon dioxide [49]. After that, it was improved by adding an extra layer of the algae bloom without a geometric thickness to describe the process of algal scum formation and movement, and it has actualized a short-term forecast of algae blooms for 3 to 5 days [55,56]. With the entire EcoTaihu model, $\mathrm{Hu}$ and his colleagues have studied the benefits of the water diversion project from Yangtze River into Lake Taihu [47] and simulated the amount of N and P removed from the lake water [50].

The EcoTaihu model applied in Lake Yangchenghu contained 11,347 active grid cells in the horizontal plane with a uniform grid size of $100 \mathrm{~m}$, a time of step $10 \mathrm{~s}$ for the hydrological module, and $100 \mathrm{~s}$ for biological modules. The calculation period was from 1 June 2015 to 31 May 2016, which covered the variation of water quality in four seasons. For convenience, the external rivers were conceptualized into 40, which included most of the major channels, natural or engineered, including 24 influent rivers and 16 effluent rivers. A vertical sigma coordinate with five evenly distributed vertical layers was applied to better simulate the bottom topography. The lake bed and water surface elevations were used to determine vertical cell thickness. The state variables considered in this study are total nitrogen, total phosphorus, and biomass of phytoplankton. Specifically, total nitrogen concentrations are the sum of ammonia nitrogen, nitrite nitrogen, nitrate nitrogen, detritus nitrogen, algae nitrogen, and zooplankton nitrogen. Total phosphorus concentrations are the sum of orthophosphate, detritus phosphorus, algae phosphorus, and zooplankton phosphorus. All the different forms of nitrogen, phosphorus, and biomass of phytoplankton are obtained from the data output in EcoTaihu model. We applied a trial-and-error method for model calibration and a parameter determination. Two quantitative fit criteria were applied in the model performance assessment: (i) an $h$ 
index, which was used in Zhang et al. [57], and (ii) a relative standard deviation $\left(A R_{d}\right)$, which was used in Hu et al. [48]. They are calculated by Equations (1) and (2):

$$
\begin{gathered}
h=\frac{\sqrt{\frac{\sum\left(C_{o b s}-C_{s i m}\right)^{2}}{n}}}{\sqrt{\sum \frac{C_{o b s}^{2}}{n}}+\sqrt{\sum \frac{C_{s i m}^{2}}{n}}} \\
A R_{d}=\frac{1}{n} \sum_{i=1}^{n} A B S\left(\frac{C_{o b s}-C_{s i m}}{C_{o b s}} \times 100\right)
\end{gathered}
$$

where $C_{\text {sim }}$ is the simulated value, $C_{o b s}$ is the observed value, and $\mathrm{n}$ is the number of observed points. The results are considered as acceptable if $0 \leq h \leq 1[57,58]$, and $A R_{d}$ is less than $45 \%$ [48,59].

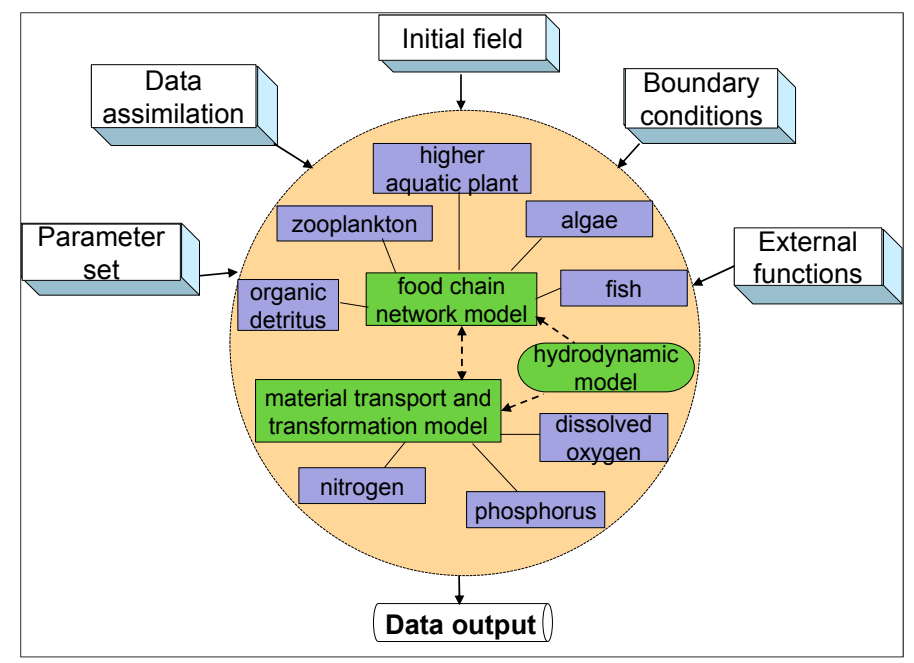

Figure 2. Components and structure of the EcoTaihu model (source: Zhang et al. [55]).

\subsection{Scenarios Design}

In 2013, some actions were taken by the People's Government of Suzhou to improve the multiple functions of Lake Yangchenghu. The various management measures mainly focused on guaranteeing the safety of drinking water and the reduction of the total pollutant emissions. Based on the recommendations of local administrative agencies, the restoration measures could be classified into three categories.

First, for the reduction of the total nutrients loading, five scenarios (S1-S5, see Table 2) were set for the daily external nutrient loads reduction, accomplished by adjusting only the tributary concentrations, but not flow. Additionally, dissolved oxygen concentration was increased in proportion to the loads reduction.

The second category was water diversion. The Qiputang River is a channel directly connected to the Yangtze River. Through three branches of the Qiputang River (Figure 1), Jie Qiao, Baiqugang Qiao and Nanxiao Qiao, the water of the Yangtze River could be transferred to the north of the central and eastern lake. TN and TP concentrations in the transferred water were set to $1.00 \mathrm{mg} \mathrm{L}^{-1}$ and $0.05 \mathrm{mg}$ $\mathrm{L}^{-1}$, according to the Grade III standard of surface water quality. Four scenarios (S6-S9, see Table 2) including different transferred time and flow rates were set in the present study to explore the optimal time and flows for its implementation.

The third category was the adjustment of the spatial distribution of the entrances of western influents. Since the location of drinking water abstraction is in the central and eastern lake (Figure 1), we analyzed whether closing some serious polluted tributaries in the western lake would improve the water quality of the total lake, and especially for the area of drinking water abstraction, since this measure could intensify the dilution of nutrients. Through setting three scenarios (S10-S12, see Table 2) 
and keeping the total nutrients loading the same as before, we explored how to arrange the western inlets and to what extent the water quality of the intake area would be improved.

Table 2. Model setting of defined scenarios.

\begin{tabular}{|c|c|c|c|}
\hline Model Scenarios & Features & Period of Time & Duration (Days) \\
\hline S1 & $5 \%$ reduction of total nutrient loads ( $5 \% \mathrm{TNL})$ & 1 June 2015-31 May 2016 & 366 \\
\hline S2 & $10 \% \mathrm{TNL}$ & - & 366 \\
\hline S3 & $20 \% \mathrm{TNL}$ & - & 366 \\
\hline S4 & $30 \% \mathrm{TNL}$ & - & 366 \\
\hline S5 & $50 \% \mathrm{TNL}$ & - & 366 \\
\hline S6 & $\begin{array}{c}40 \mathrm{~m}^{3} \mathrm{~s}^{-1} \text { flow rate of water transfer in } \\
\text { winter-spring (40 WTWS) }\end{array}$ & $\begin{array}{l}\text { 1 January 2016-31 May } 2016 \\
\text { (total volume: } 5.18 \times 10^{8} \mathrm{~m}^{3} \text { ) }\end{array}$ & 150 \\
\hline S7 & 60 WTWS & (total volume: $7.78 \times 10^{8} \mathrm{~m}^{3}$ ) & 150 \\
\hline S8 & $\begin{array}{c}40 \mathrm{~m}^{3} \mathrm{~s}^{-1} \text { flow rate of water transfer in } \\
\text { autumn-winter (40 WTAW) }\end{array}$ & $\begin{array}{l}1 \text { October 2015-31 December } 2015 \\
\left(\text { total volume: } 3.18 \times 10^{8} \mathrm{~m}^{3}\right)\end{array}$ & 92 \\
\hline S9 & 60 WTAW & (total volume: $\overline{4} .77 \times 10^{8} \mathrm{~m}^{3}$ ) & 92 \\
\hline S10 & $\begin{array}{c}\text { Water inflow of Baidang River added to } \\
\text { Shengtanggang River }\end{array}$ & 1 June 2015-31 May 2016 & 366 \\
\hline S11 & $\begin{array}{l}\text { Water inflow of Baidang, Litanghe, Jiminting } \\
\text { River added to Shengtanggang River }\end{array}$ & - & 366 \\
\hline $\mathrm{S} 12$ & $\begin{array}{c}\text { Water inflow of all other rivers added to } \\
\text { Shengtanggang River }\end{array}$ & - & 366 \\
\hline
\end{tabular}

- represents the same with upper contents.

\section{Model Calibration}

The results of the calibrated seasonal simulation in the state variables are presented in Figures 3-6. The simulations agreed acceptably with the observations, where all of the $h$ values were less than 1 (Table 3). The $A R_{d}$ values were all less than $45 \%$ except for TP, indicating a relatively poor calibration for the total phosphorus (Table 3, Figure 4). The observation of TN in the western and central lake showed stronger change versus month than the eastern lake; the loads input from inflows may have an influence on this. The differences between simulations and observations of TN were small, but the simulated value did not capture some peaks in winter (Figure 3). As for TP, it varied quickly versus month compared with TN and BP (Figure 4). In general, the simulated results have the same trends with the observed values, going up in summer, and decreasing in winter. The BP concentration was more stable than the other state variables (Figure 5), and slightly increased in summer and decreased in winter. This pattern was captured by the model, but the simulated seasonal variation was more exaggerated in the central and eastern lake. The simulated BP in the central lake $\left(2.38 \mathrm{mg} \mathrm{L}^{-1}\right) \mathrm{was}$ higher than in the western lake $\left(2.31 \mathrm{mg} \mathrm{L}^{-1}\right)$ and eastern lake $\left(1.89 \mathrm{mg} \mathrm{L}^{-1}\right)$, although higher TN and TP concentrations prevail in the western area, indicating that the simulated results of BP was also influenced by other factors besides nutrient concentration, such as the advective transport by water currents. Finally, DO was also shown in the calibration results (Figure 6). It experienced a strongly seasonal change, in which it decreased in summer and peaked in winter, opposite the water temperature. The mainly calibrated model parameters are shown in Table 4 . The other parameters can be seen in $\mathrm{Hu}$ et al. [48].

Table 3. The quantitative fit criteria of the state variables in the calibrated model.

\begin{tabular}{ccc}
\hline Parameters & $\boldsymbol{h}$ & $\boldsymbol{A R}_{\boldsymbol{d}}(\%)$ \\
\hline TN & 0.30 & 25.73 \\
TP & 0.36 & 48.00 \\
BP & 0.24 & 21.40 \\
DO & 0.10 & 7.99 \\
\hline
\end{tabular}


Table 4. Key calibration coefficients used for the EcoTaihu model application.

\begin{tabular}{ccc}
\hline Parameter & Value & Unit \\
\hline Maximum growth rate of submerged plants & 1.8 & $\mathrm{~d}^{-1}$ \\
Maximum growth rate of phytoplankton & 1.1 & $\mathrm{~d}^{-1}$ \\
Settling velocity of detritus & 0.001 & $\mathrm{~m} \mathrm{~d}^{-1}$ \\
Oxidation rate of ammonia nitrogen at $20^{\circ} \mathrm{C}$ & 0.2 & $\mathrm{~d}^{-1}$ \\
Releasing velocity of dissolved phosphorus from sediments & 0.0025 & $\mathrm{~d}^{-1}$ \\
Oxidation rate of nitrate nitrogen at $20^{\circ} \mathrm{C}$ & 0.6 & $\mathrm{~d}^{-1}$ \\
\hline
\end{tabular}

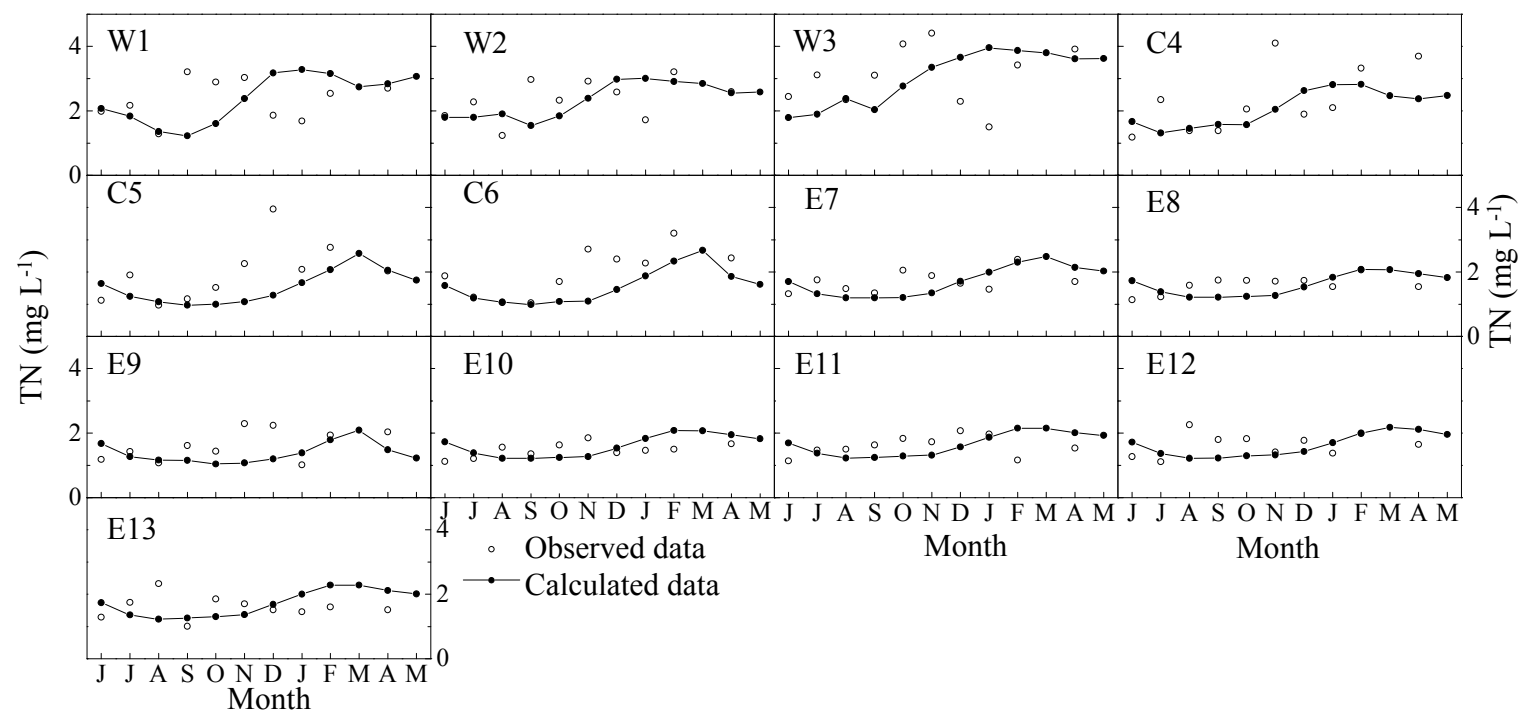

Figure 3. TN $\left(\mathrm{mg} \mathrm{L}^{-1}\right)$ model (line + dots) and observed data (open dots) at 13 sites for June 2015 to May 2016.

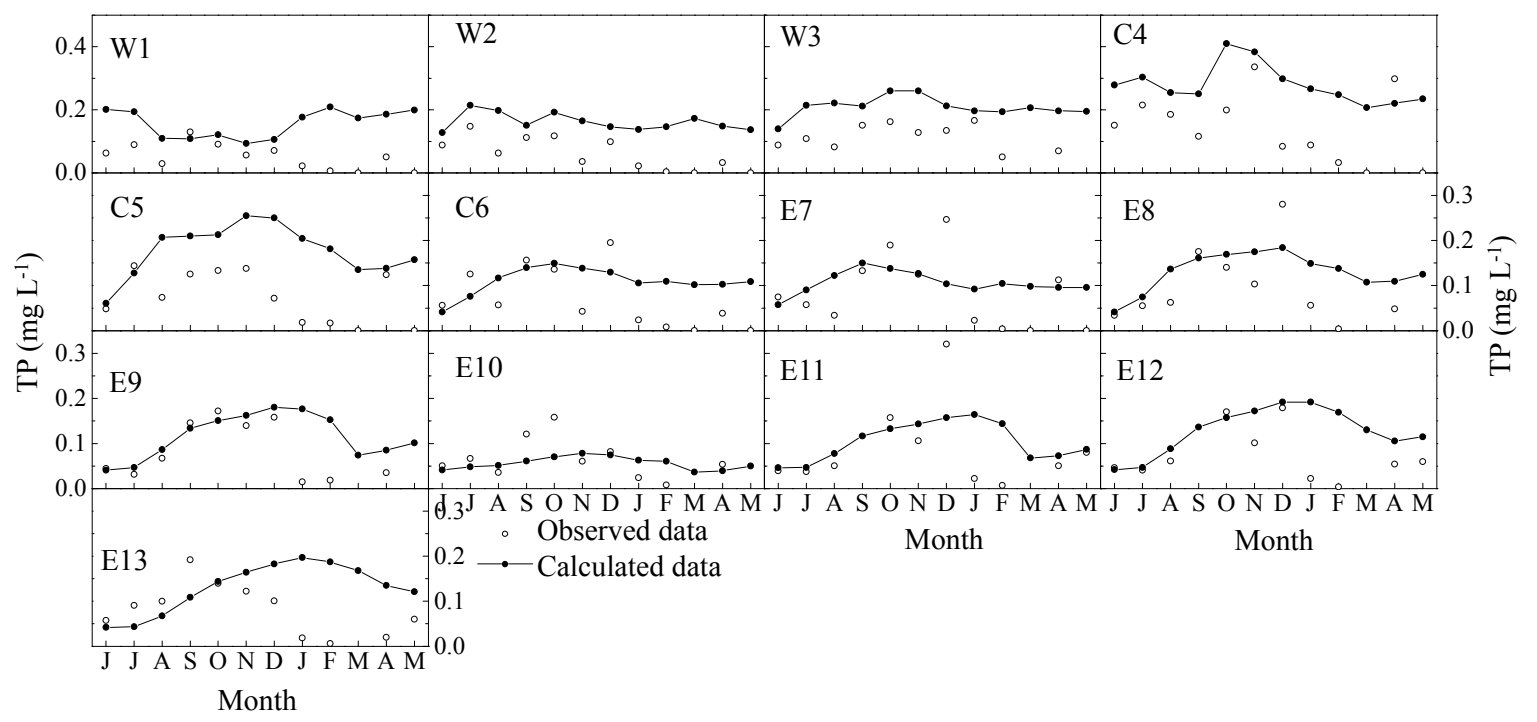

Figure 4. TP $\left(\mathrm{mg} \mathrm{L}^{-1}\right)$ model (line + dots) and observed data (open dots) at 13 sites for June 2015 to May 2016. 


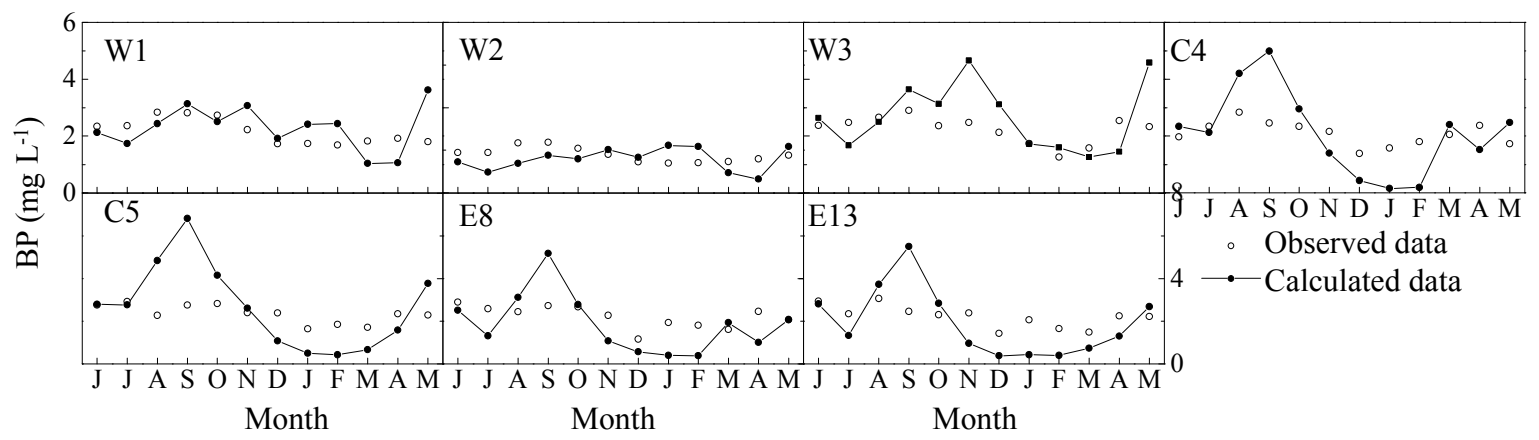

Figure 5. BP (mg L $\left.{ }^{-1}\right)$ model (line + dots) and observed data (open dots) at 7 sites for June 2015 to May 2016.

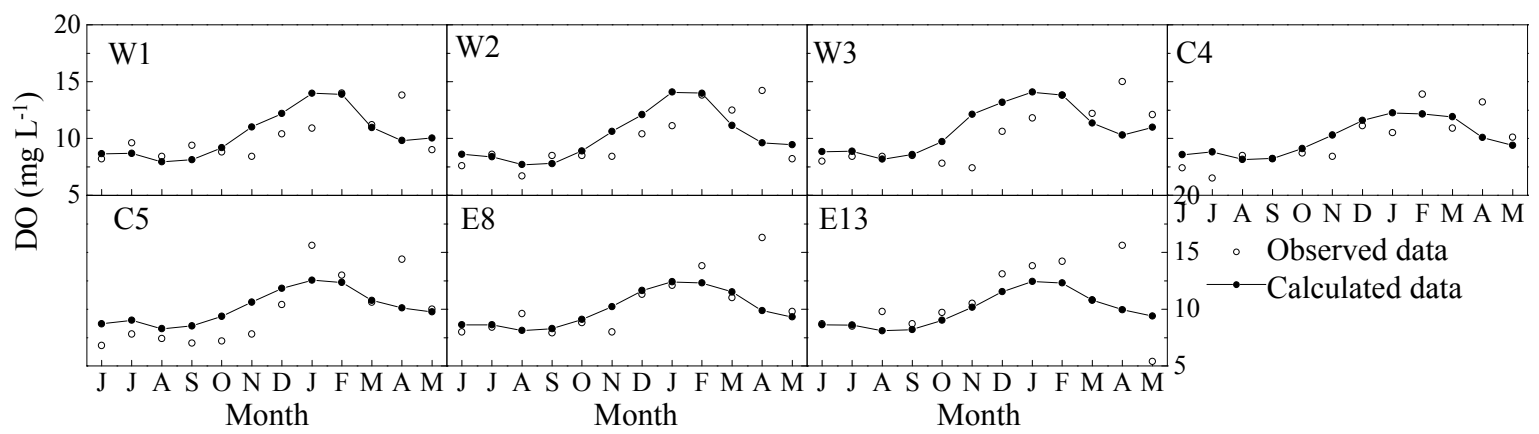

Figure 6. DO ( $\left.\mathrm{mg} \mathrm{L}^{-1}\right)$ model (line + dots) and observed data (open dots) at 7 sites for June 2015 to May 2016.

\section{Results and Discussion}

\subsection{Loading Reduction}

The time series plots of TN, TP, and BP for the scenarios S1-S5 in three sub-zones showed that the concentration of TN, TP, and BP gradually decreased in proportion to the nutrient reduction in the inflows (Figure 7), and the effectiveness demonstrated clear spatial variability. Similar studies have been implemented in Lake Taihu and Lake Erie, although there were no results showing the effective differences in spatial variability, since they only analyzed mean data of the entire lake $[20,46]$. For S3, the annual average concentrations of TN and TP decreased by $19 \%, 13 \%$ and $15 \%$ for TN, $21 \%$, $20 \%$, and $17 \%$ for TP in western, central and eastern lake, respectively. Obviously, the western lake experienced the highest improvement of water quality for both TN and TP, because most inflows enter the lake in the western part, while the annual average concentration of BP decreased by $10 \%, 17 \%$, and $16 \%$ in western, central, and eastern lakes, respectively. Compared with TN and $\mathrm{TP}$, the concentration of BP had the lowest improvement in the western lake although it was the most deteriorated area, and the most significant improvement appeared in the central lake. We interpret this finding as a result of the prevailing west-to-east water current: algae were quickly exported from the western into the central lake and the incorporation of nutrients into algal biomass therefore takes place in the central and eastern parts. Gui et al. [60] also suggested that the positive correlation between Chl-a and TN could only be observed in the dry season (May) in Lake Yangchenghu, and no correlation between Chl-a and TN or TP was detected in the flood season (October). The highest value of BP in Lake Yangchenghu could be monitored in the central lake during the flood season. 


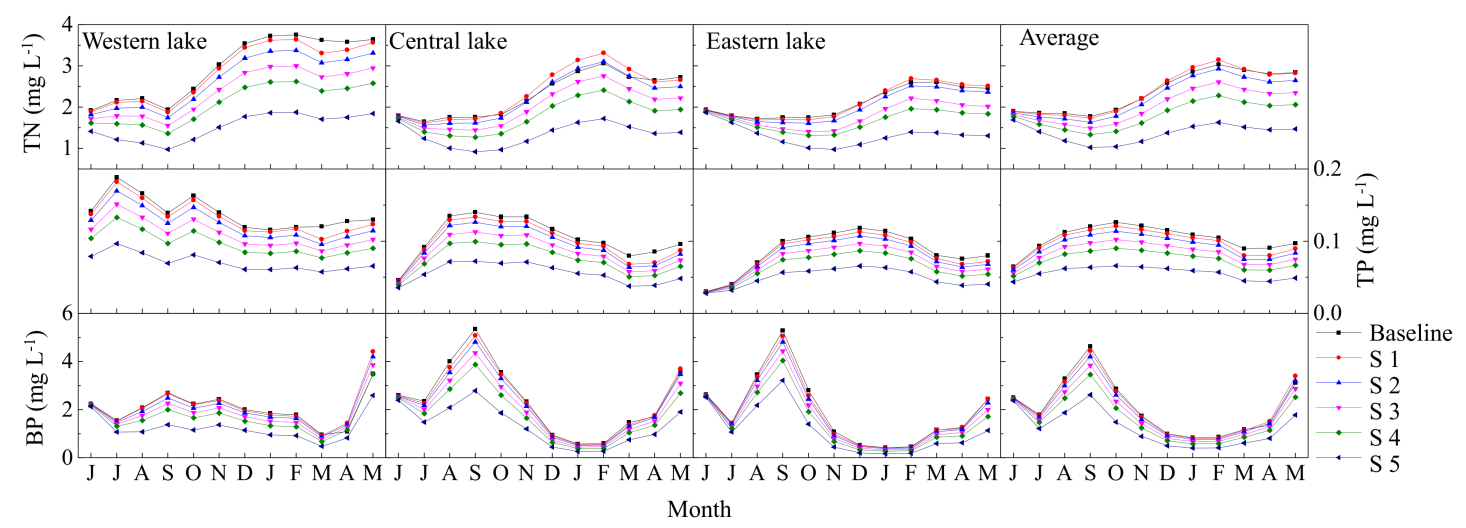

Figure 7. The concentration of TN, TP, and BP in Lake Yangchenghu under different nutrient proportions of baseline load in influent rivers.

The load-response curves (Figure 8) demonstrated a linear relationship between load reduction and nutrients or BP, respectively. This finding suggested that the average water quality of Lake Yangchenghu was directly influenced by external loading, and that the improvement effectiveness was proportionate to the percentage of load reduction. Previous studies have similarly reported a strong linear relationship between maximum bloom biomass and summer averaged Chl-a versus the external TP loads, indicating that variations in TN, TP, and net algal growth are predominantly influenced by external loads, and that other factors, such as the meteorological conditions, remain less influential $[18,20]$. The load-response curves can be used to define target $\mathrm{N}$ and $\mathrm{P}$ loads for achieving a specific eutrophication status. To improve the water level to Grade III for TN and TP $\left(1.00 \mathrm{mg} \mathrm{L}^{-1}\right.$ and $0.05 \mathrm{mg} \mathrm{L}^{-1}$ respectively), reductions of approximately $72 \%$ and $53 \%$ of $\mathrm{N}$ and P loads from the influent rivers would be necessary. In Lake Dianchi, another shallow lake in China, Wang et al., suggested a load reduction of $80 \%$ in order to achieve a Grade III water quality [37], and another study recommended $70 \%$ loads reduction for this lake [39]. Therefore, substantial load reductions are required to improve water quality and ambiguous management measures need to be implemented.

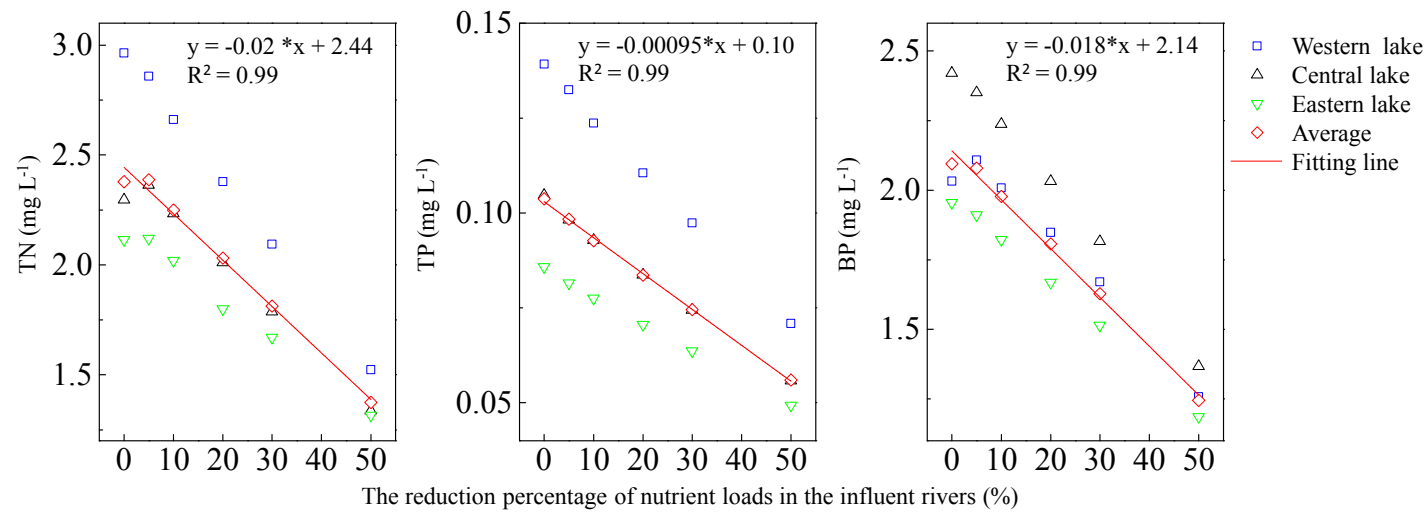

Figure 8. Load-responses curve for TN, TP, and BP.

\subsection{Water Transfer}

The locations of input water entrances in Lake Yangchenghu influenced the effectiveness of water transfer by affecting the hydrodynamic process in different subzones of the lake. Compared with the baseline without water transfer, a notable reduction of TN, TP, and BP concentrations was observed in the central and eastern lake (Figure 9), simply because the transferred water entered the system through the central and eastern lake. A certain improvement of water quality could also be seen in the western lake, suggesting that water transfer is affecting the water quality in the whole lake. However, 
in Lake Chenghai, the sites corresponding to the entry point of water diverted have larger percentage of improvement in TN and TP than in others [61]. The effectiveness of water transfer also only existed in some specific areas in Lake Taihu [8,47]. This phenomenon occurred because the transferred water made it impossible to cover all of the subzones evenly due to their large size $[8,47]$.

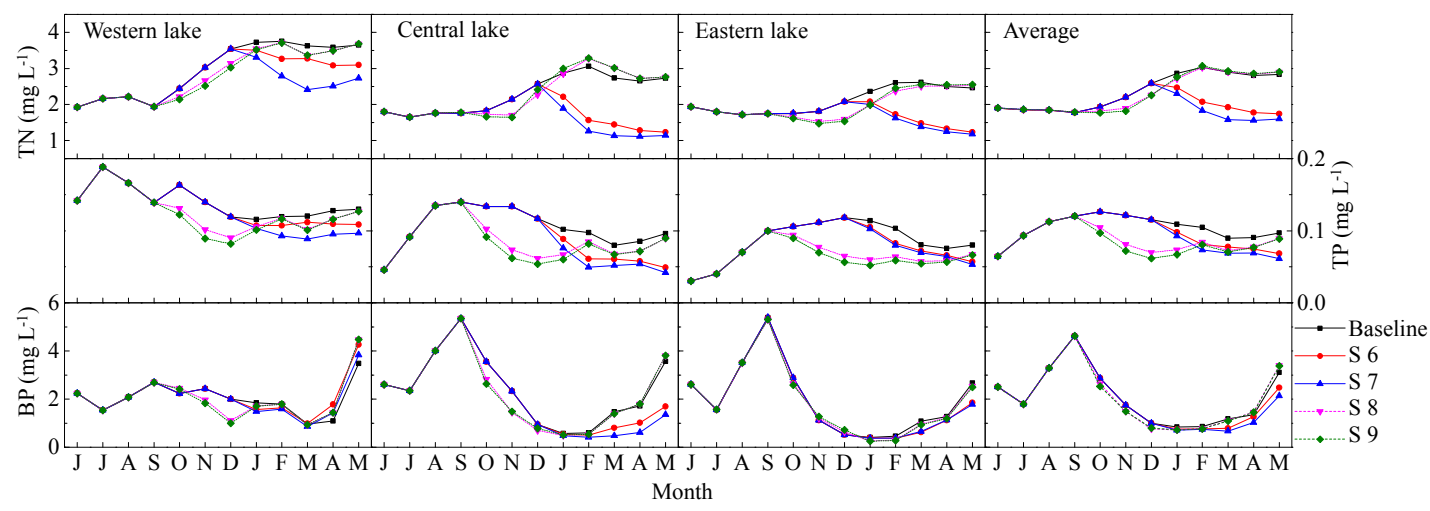

Figure 9. The concentration of TN, TP, and BP in Lake Yangchenghu during water transfer.

In addition, the quantity of water being diverted had no significant effect on the improvement of water quality in this study. Obviously, there was no more noticeable improvement of water quality when the flow rate of the transferred water was enhanced to $60 \mathrm{~m}^{3} \mathrm{~s}^{-1}$ (S7 and S9). It was reported that a volume of water of about $15 \%$ and $25 \%$ of the whole lake volume added to Lake Taihu in winter-spring 2002 and summer-autumn 2003 was able to clearly decrease the nutrient concentration by $40 \%$ in the southern and eastern regions of the lake in January-April 2002, and 20\% in the northern and southwestern regions of the lake in August-November 2003, respectively [8]. The restoration of Moses Lake, Washington, U.S.A., by water dilution suggested that $126 \%$ of lake water volume $\left(193.0 \times 10^{6} \mathrm{~m}^{3}\right)$ input in March-September 1977 could decrease TN, TP, and Chl-a by about 40\%, 50\%, and $40 \%$, respectively [62]. In the present study, $135 \%$ of the lake volume transferred in autumn-winter could decrease the concentration of TP by $16.3 \%$. About $219.0 \%$ of the lake volume transferred in winter-spring reduced TN and BP by $15.6 \%$ and $5.2 \%$ for the total lake. This water quality improvement in Lake Yangchenghu is a direct consequence of the water renewal by dilution.

Furthermore, the effectiveness of diversion could be strongly influenced by the concentration differences between the lake water and the inflow water. Notable water quality improvement after water dilution in 1977 and 1978 was observed in most areas of the lake, because the TN and TP concentrations in the diverted water were only $1 / 7$ and $1 / 8$ of that in lake water $[62,63]$. In the present study, it was clear that the improvement of TP during the diversion of autumn-winter (October to December) was significantly higher than the transfer in winter-spring despite the relatively lower amount of transferred volume in latter period, while TN and BP experienced a higher improvement during the diversion in winter-spring (January-May). This phenomenon occured mainly because the higher concentration of TP in the autumn could be intensely diluted by the diverted water with lower TP. In contrast, TN and BP showed relatively higher values from January to May; water transfer in this period would inevitably contribute to the notable improvement of TN and BP. Accordingly, diversion had a lower impact on the improvement of parameters in other seasons mainly because the slight differences of parameter concentrations between the diverted water and lake water.

\subsection{Entrances Adjustment of Tributaries}

Eight sites were selected to investigate the responses of $\mathrm{TN}, \mathrm{TP}$, and $\mathrm{BP}$ in a specific area to the entrances adjustment of inflows (see Figure 10). Among them, E12, C6, and E7 represent the water quality of the existed drinking water source area and the proposed drinking water source areas, respectively (Figure 1). Although it has been suggested that the degree of eutrophication of 
the lake depends on the spatio-temporal distribution of the external loads from the watershed via tributaries [64], most research mainly focuses on the nutrient concentrations of the tributaries, instead of their spatial distribution. In Lake Yangchenghu, the TN and TP concentration decreased significantly at W3 and increased at W1 and W2 simultaneously in these three scenarios (Figure 10). Contrary to TN and TP, BP in the northern part of the western lake (site W1 and W2) showed an increase trend in the early stage, after impeding the southern tributaries entrances, which was mainly caused by the higher water flushing rate taking the algae from the northern part of the western lake to the southern part. This phenomenon also indicated that the short-term effect of adjustment tributaries entrances on the BP concentration happened by changing the hydrological processes, instead of the nutrient concentration. Most lake areas including drinking water source areas (site C6, E7, and E12) experienced a more deteriorated effectiveness of water quality because of the effect of hydrodynamic conditions. In scenario 12, TN, TP, and BP concentrations in the total lake increased by $2.06 \%, 9.90 \%$, and $1.90 \%$, respectively. As a whole, the narrowing of the inflowing rivers could not successfully improve the water quality of TN, TP, and BP in the area of drinking water source, it would only decrease the TN, $\mathrm{TP}$, and BP concentration in the southern part of the western lake where pollutants input from Baidang River are transferred to other tributaries located in the northern part.

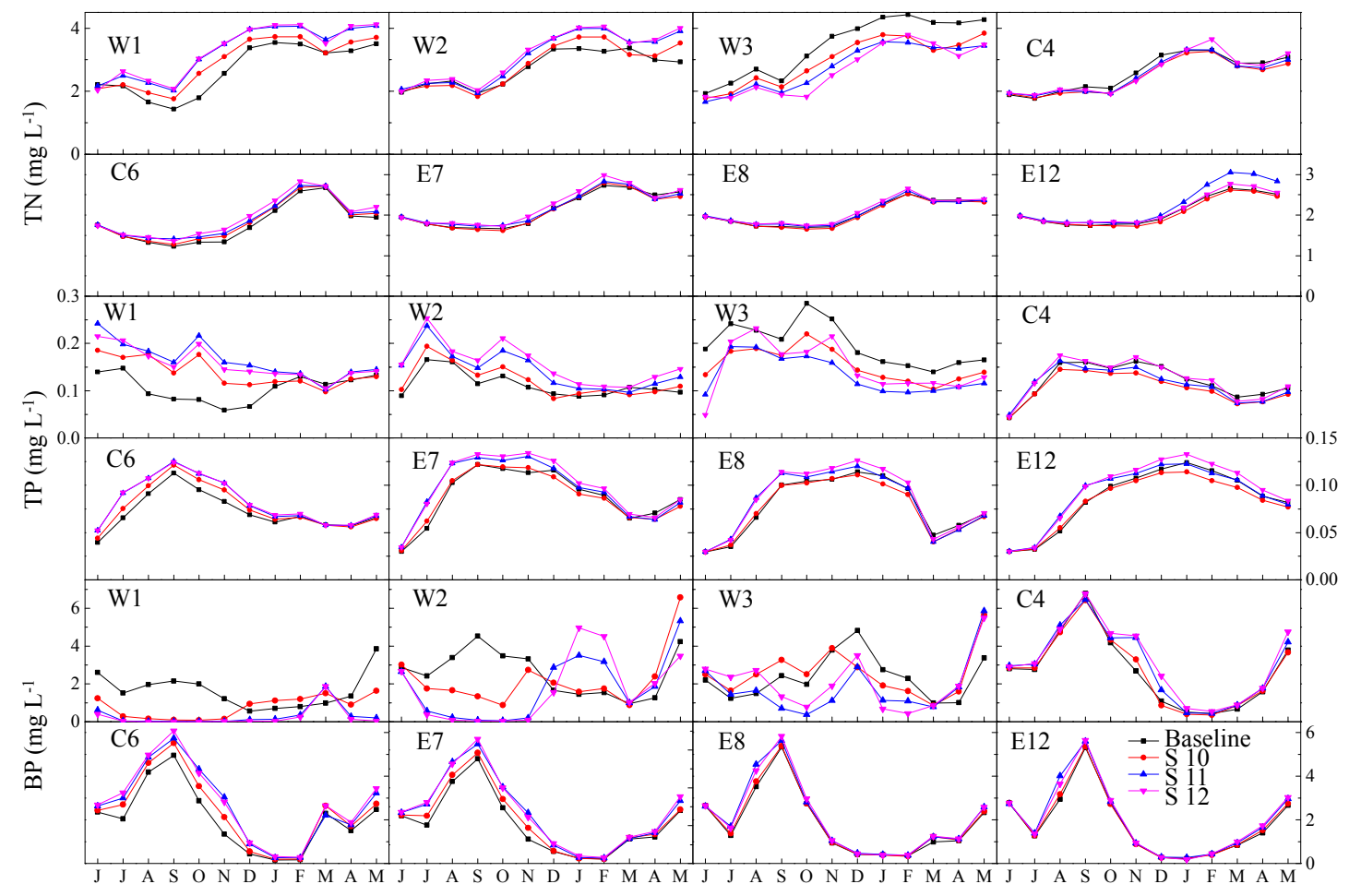

Figure 10. The concentration of TN, TP, and BP in Lake Yangchenghu after entrances adjustment of tributaries.

\subsection{Water Quality Response Comparisons between Restoration Measures}

The effects of the 12 scenarios on $\mathrm{TN}, \mathrm{TP}$, and BP can be evaluated on basis of the relative and absolute changes in comparison to the baseline scenario (Table 5). Overall, compared with the three kinds of restoration measures, the scenario of $50 \%$ external reduction of total nutrient loads (S5) had the most significant improvement of water quality, even the effect of scenario S3 (20\% loads reduction) on the TN improvement was similar with the water transfer of $40 \mathrm{~m}^{3} \mathrm{~s}^{-1}$ in winter-spring (S6). Spatially narrowing western tributaries into one inflow (S12) failed to improve the water quality of the lake water. In addition, the water quality parameters responded to the three restoration measures differently. Apparently, TP demonstrated the strongest improvement in the loads reduction scenarios, 
indicating that TP was more influenced by inflowing loads compared to TN. This phenomenon could be attributed to the different retention mechanics between $\mathrm{N}$ and $\mathrm{P}$ in lake ecosystems. As is commonly known, most retained TP in lakes is deposited into sediments. Assuming the amount of TP flowing out and deposition rates remain unchanged, the reduction of the inflowing loads of TP would inevitably lead to the corresponding reduction of TP concentration in the lake water. For TN, denitrification is also an essential retention process besides deposition, which could be an important reason for the lower improvement rate of TN in lake water because of its complex retention processes. Since BP has a strong relationship with TN and TP, it showed a similar pattern to TN and TP. The different improvement of $\mathrm{TN}, \mathrm{TP}$, and $\mathrm{BP}$ in water diversion could be explained by the concentration differences between the diverted water and lake water, as previously explained.

Table 5. Statistics for TN, TP, and BP under different management measures in the whole lake.

\begin{tabular}{|c|c|c|c|c|c|c|}
\hline & \multicolumn{2}{|c|}{ TN } & \multicolumn{2}{|c|}{ TP } & \multicolumn{2}{|c|}{ BP } \\
\hline & $\begin{array}{c}\text { Mean } \\
\text { Change }(\%)\end{array}$ & $\begin{array}{l}\text { Annual Average } \\
\left(\mathrm{mg} \mathrm{L}^{-1}\right)\end{array}$ & $\begin{array}{c}\text { Mean Change } \\
(\%)\end{array}$ & $\begin{array}{l}\text { Annual Average } \\
\quad\left(\mathrm{mg} \mathrm{L}^{-1}\right)\end{array}$ & $\begin{array}{c}\text { Mean Change } \\
(\%)\end{array}$ & $\begin{array}{c}\text { Annual Average } \\
\left(\mathrm{mg} \mathrm{L}^{-1}\right)\end{array}$ \\
\hline Baseline & $\mathrm{N} / \mathrm{A}$ & 2.38 & $\mathrm{~N} / \mathrm{A}$ & 0.104 & $\mathrm{~N} / \mathrm{A}$ & 2.10 \\
\hline S1 & 0.39 & 2.39 & -5.12 & 0.098 & -0.79 & 2.08 \\
\hline S2 & -5.44 & 2.25 & -10.62 & 0.093 & -5.61 & 1.98 \\
\hline S3 & -14.60 & 2.03 & -19.37 & 0.084 & -13.76 & 1.81 \\
\hline S4 & -23.79 & 1.81 & -28.17 & 0.075 & -22.29 & 1.63 \\
\hline S5 & -42.26 & 1.37 & -45.99 & 0.056 & -40.59 & 1.24 \\
\hline S6 & -15.60 & 2.01 & -7.34 & 0.096 & -5.17 & 1.99 \\
\hline S7 & -19.54 & 1.91 & -10.13 & 0.093 & -8.11 & 1.93 \\
\hline S8 & -2.77 & 2.31 & -16.26 & 0.087 & -2.37 & 2.05 \\
\hline S9 & -2.80 & 2.31 & -19.25 & 0.084 & -2.86 & 2.04 \\
\hline S10 & -1.56 & 2.34 & -3.44 & 0.100 & 0.92 & 2.11 \\
\hline S11 & 1.99 & 2.43 & 3.73 & 0.108 & 1.15 & 2.12 \\
\hline S12 & 2.06 & 2.43 & 9.90 & 0.114 & 1.90 & 2.13 \\
\hline
\end{tabular}

Watershed nutrients loading is the primary factor driving variations in water quality in such a strongly flushed lake. A successful approach would therefore be to limit daily total nutrient loads, which is an essential, sensible, and feasible strategy for controlling eutrophication. A total of $72 \% \mathrm{TN}$ and 53\% TP reduction is required if meeting Grade III level of water quality in Lake Yangchenghu. The reduction of total daily nutrient loads may show delay effects because of the lake size and internal loading. It has been suggested that when the internal $\mathrm{P}$ loads and catchment $\mathrm{P}$ loads reduction measures are applied simultaneously, rapid recovery can be achieved $[65,66]$.

Water diversion can be an effective measure to reduce eutrophication level of lakes, in which a large quantity of low-nutrient water is transferred to a eutrophic lake. Although the percentage of water quality improvement is small compared to $30 \%$ of total nutrients reduction in Lake Yangchenghu, the advantages of water transfer are that they are at relatively low costs, and show a quick response in nutrient reduction when suitable dilution water is available [8]. The implementation needs to account for several aspects. First, the improvement area of water quality would be limited to a certain region because of the lake size. As shown above, the introduction of Yangtze River water could significantly improve the water quality in the central and eastern lake. Second, it is essential to find a large amount of low-nutrient water for a certain period of time. We have found that a large difference in $\mathrm{N}$ and $\mathrm{P}$ concentration between inflowing water and lake water leads to a deeper water quality improvement. Third, the quantity, duration, and timing of water transfer should also be considered, all of which determine the costs and effectiveness. Comparing S6 (winter-spring, $40 \mathrm{~m}^{3} \mathrm{~s}^{-1}$ ) with S8 (autumn-winter, $40 \mathrm{~m}^{3} \mathrm{~s}^{-1}$ ) (Table 5), the improvement of TN and TP showed a big difference. However, the quantity of water transfer in this study was not essential as shown above.

Entrances adjustment of influents is a novel restoration measure. We assumed that this measure could play a role in the water quality in the southern part (drinking water source) mainly through enlarging the self-purification of nutrients in the lake. Spatial adjustment of industries and populations to improve water quality has been studied in Lake Dianchi [67]. However, in shallow lakes, which 
are the most common lake type in China, no one has studied spatial adjustment of inflowing rivers, especially using 3-D modeling method. According to the results in the present study, impeding one main inflow would definitely improve the water quality in the southern bay of the western lake, although a deterioration in water quality was observed in the scenarios of impeding main rivers besides Baidang River (S11, S12).

Compared with the three kinds of measures, external loads reduction is the optimal measure to improve the water quality of Lake Yangchenghu; the second one is water transfer at the rate of $40 \mathrm{~m}^{3} \mathrm{~s}^{-1}$. The alleviation of eutrophication in this lake requires balancing these two approaches appropriately. However, narrowing the main inflow tributaries could not be developed to decrease the TN and TP concentrations in the drinking water source areas. It is noteworthy that it would be better to calculate and compare the environmental benefits between different scenarios regarding the costs when making restoration measures. However, there have uncertainties and big differences in the costs for each restoration measure. The factors including the amounts of diverted water and electricity consumption, the size of constructed channel for water transfer, and the labors fee, have an essential influence on the total costs during the water transfer implementation. Moreover, for the loads reduction, the costs for removing nitrogen and phosphorus are different because the technologies for wastewater treatment to reduce nitrogen versus phosphorus differ markedly. Therefore, due to the spatio-temporal nitrogen and phosphorus concentration changes in the inflowing rivers, the costs for removing both $\mathrm{N}$ and $\mathrm{P}$ are difficult to calculate.

\subsection{Possibities and Limitations of Using the EcoTaihu Model}

There are some advantages in applying the EcoTaihu model in this study. First, the EcoTaihu model successfully coupled hydrodynamic processes, nutrient transformation, and food chain networks together. It would be more accurate to calculate the concentrations of water quality parameters and biomass of phytoplankton in short and long term because of the better-defined mechanisms and components of the lake ecosystem. Second, the EcoTaihu model is a 3-D model: it uses a vertical sigma coordinate with evenly distributed five vertical layers, which is better to simulate the bottom topography. Also, it allows us to investigate the spatial water quality responses to different management measures. Third, the EcoTaihu model is applicable to other lakes in the subtropical zone. Till now, the EcoTaihu model has successfully been used in Lake Taihu [47,48], Lake Yangchenghu (present study), etc. The model calibration results suggest that the EcoTaihu model is applicable for these lakes and is reliable for further application.

Nevertheless, there are still some limitations in the application of this model. For instance, the sediment submodule of the EcoTaihu model is imperfect. It considers a 10-cm depth of surface sediments as a whole, and omits vertical molecular diffusion, adsorption and desorption processes, and more. Consequently, it is inaccurate for the calculation of internal loading. In addition, EcoTaihu model does not include benthic organisms. The benthic organisms are an important food chain level in the shallow lake ecosystem, because some benthic fauna could filter-feed the suspended matter and influence the exchange of nutrient between sediment and lake water [68]. Therefore, excluding the benthic processes also affects the water quality, especially in deep lake water. Furthermore, as a coupled ecological modeling, there are inevitably some uncertainties from the measured data, such as the inflow rates and outflow rates, meteorological data, and nutrient concentrations for the initial values of the model running and model calibration. In the future, the EcoTaihu model would need to be developed through the optimization of the sediment submodule and the incorporation of the benthic food chain.

\section{Summary and Conclusions}

The simulated results showed that a 50\% loads reduction (S5) was the most effective scenario, with around $42 \% \mathrm{TN}, 46 \% \mathrm{TP}$, and 41\% BP water quality improvement in the whole lake. Approximately $72 \%$ and $53 \%$ reductions of TN and TP loads from the influent rivers would be necessary in order 
to improve the water level to Grade III in Lake Yangchenghu. Water diversion of $40 \mathrm{~m}^{3} \mathrm{~s}^{-1}$ in winter-spring (S6) could improve TN and BP by $16 \%$ and $5 \%$, respectively. Water diversion of $40 \mathrm{~m}^{3}$ $\mathrm{s}^{-1}$ in autumn-winter (S8) would improve TP by $16 \%$. Proper timing of water transfer should be determined based on the target water quality variable. Narrowing the western inflows would not improve the water quality in the drinking water source areas.

Author Contributions: Conceptualization, W.H. and Z.P.; Methodology, W.H.; Software, W.H. and Z.P.; Validation, Y.W.; Formal Analysis, Y.W.; Investigation, Z.P., Y.W. and Y.Z.; Writing-Original Draft Preparation, Y.W.; Writing-Review \& Editing, W.H. and K.R.; Visualization, Y.W.; Supervision, W.H. and K.R.

Funding: This research was funded by the Natural Science Foundation of Jiangsu Province (BK20151064) and the Environmental Protection Bureau of Suzhou (SZLHZ2014-G-003).

Acknowledgments: We thank Xiaolong Wang of the Nanjing Institute of Geography and Limnology for a part of the field sampling and monitoring data.

Conflicts of Interest: The authors declare no conflict of interest.

\section{References}

1. Conley, D.J.; Paerl, H.W.; Howarth, R.W.; Boesch, D.F.; Seitzinger, S.P.; Havens, K.E.; Lancelot, C.; Likens, G.E. Controlling eutrophication: Nitrogen and phosphorus. Science 2009, 323, 1014-1015. [CrossRef] [PubMed]

2. Xu, H.; Paerl, H.W.; Qin, B.Q.; Zhu, G.W.; Gao, G. Nitrogen and phosphorus inputs control phytoplankton growth in eutrophic Lake Taihu, China. Limnol. Oceanogr. 2010, 55, 420-432. [CrossRef]

3. Wang, X.L.; Zhang, M.; Yin, J. Composition and influential factors of phytoplankton function groups in Lake Chaohu. J. Lake Sci. 2018, 30, 431-440. (In Chinese)

4. Conley, D.J.; Paerl, H.W.; Howarth, R.W.; Boesch, D.F.; Seitzinger, S.P.; Havens, K.E.; Lancelot, C.; Likens, G.E.; Jacoby, C.A.; Frazer, T.K. Eutrophication: Time to adjust expectations [with Response]. Science 2009, 324, 723. [CrossRef]

5. Mallin, M.A.; Mciver, M.R.; Wells, H.A.; Parsons, D.C.; Johnson, V.L. Reversal of eutrophication following sewage treatment upgrades in the new river estuary, North Carolina. Estuaries Coasts 2005, 28, 750-760. [CrossRef]

6. Jeppesen, E.; Søndergaard, M.; Meerhoff, M.; Lauridsen, T.L.; Jensen, J.P. Shallow lake restoration by nutrient loading reduction-Some recent findings and challenges ahead. Hydrobiology 2007, 584, 239-252. [CrossRef]

7. Roberta, F.; Antenucci, J.P. The impact of transfers on water quality and the disturbance regime in a reservoir. Water Res. 2011, 45, 5873-5885.

8. Hu, L.; Hu, W.; Zhai, S. Effects on water quality following water transfer in Lake Taihu, China. Ecol. Eng. 2010, 36, 471-481. [CrossRef]

9. Amano, Y.; Sakai, Y.; Sekiya, T.; Takeya, K.; Taki, K.; Machida, M. Effect of phosphorus fluctuation caused by river water dilution in eutrophic lake on competition between blue-green alga Microcystis aeruginosa and diatom Cyclotella sp. J. Environ. Sci. 2010, 22, 1666-1673. [CrossRef]

10. Jensen, H.S.; Reitzel, K.; Egemose, S. Evaluation of aluminum treatment efficiency on water quality and internal phosphorus cycling in six Danish lakes. Hydrobiology 2015, 751, 189-199. [CrossRef]

11. Spears, B.M.; Lürling, M.; Yasseri, S.; Castro-Castellon, A.T.; Gibbs, M.; Meis, S.; Mcdonald, C.; Mcintosh, J.; Sleep, D.; Van, O.F. Lake responses following lanthanum-modified bentonite clay (Phoslock ${ }^{\circledR}$ ) application: An analysis of water column lanthanum data from 16 case study lakes. Water Res. 2013, 47, 5930-5942. [CrossRef] [PubMed]

12. Spears, B.M.; Dudley, B.; Reitzel, K.; Rydin, E. Geo-engineering in lakes-a call for consensus. Environ. Sci. Technol. 2013, 47, 3953-3954. [CrossRef] [PubMed]

13. Xu, D.; Ding, S.; Sun, Q.; Zhong, J.; Wu, W.; Jia, F. Evaluation of in situ capping with clean soils to control phosphate release from sediments. Sci. Total Environ. 2012, 438, 334-341. [CrossRef] [PubMed]

14. Jing, L.D.; Wu, C.X.; Liu, J.T.; Wang, H.G.; Ao, H.Y. The effects of dredging on nitrogen balance in sediment-water microcosms and implications to dredging projects. Ecol. Eng. 2013, 52, 167-174. [CrossRef]

15. Yenilmez, F.; Aksoy, A. Comparison of phosphorus reduction alternatives in control of nutrient concentrations in Lake Uluabat (Bursa, Turkey): Partial versus full sediment dredging. Limnol.-Ecol. Manag. Inland Waters 2013, 43, 1-9. [CrossRef] 
16. Ciurli, A.; Zuccarini, P.; Alpi, A. Growth and nutrient absorption of two submerged aquatic macrophytes in mesocosms, for reinsertion in a eutrophicated shallow lake. Wetlands Ecol. Manag. 2009, 17, 107-115. [CrossRef]

17. Benndorf, J.; Böing, W.; Koop, J.; Neubauer, I. Top-down control of phytoplankton: The role of time scale, lake depth and trophic state. Freshw. Biol. 2002, 47, 2282-2295. [CrossRef]

18. Rucinski, D.K.; Depinto, J.V.; Beletsky, D.; Scavia, D. Modeling hypoxia in the central basin of Lake Erie under potential phosphorus load reduction scenarios. J. Great Lakes Res. 2016, 42, 1206-1211. [CrossRef]

19. Zhang, W.T.; Rao, Y.R. Application of a eutrophication model for assessing water quality in Lake Winnipeg. J. Great Lakes Res. 2012, 38, 158-173. [CrossRef]

20. Verhamme, E.M.; Redder, T.M.; Schlea, D.A.; Grush, J.; Bratton, J.F.; Depinto, J.V. Development of the Western Lake Erie Ecosystem Model (WLEEM): Application to connect phosphorus loads to cyanobacteria biomass. J. Great Lakes Res. 2016, 42, 1193-1205. [CrossRef]

21. Zhai, S.J.; Hu, W.P.; Zhu, Z.C. Ecological impacts of water transfers on Lake Taihu from the Yangtze River, China. Ecol. Eng. 2010, 36, 406-420. [CrossRef]

22. Chu, M.M. The countermeasures of water quality protection of Lake Yangchenghu. Jiangsu Water Conservancy 2004, 36-37. (In Chinese)

23. Liang, C.; Li, X.; Ran, X. The eutrophication process and trend of Lake Yangchenghu based on spati-temporal distribution. J. Jinan Univ. (Nat. Sci. Med. Ed.) 2015, 36, 443-447. (In Chinese)

24. Liu, C.W.; Zhang, L.J.; Zhao, Z.Q. Research on numerical simulation of improving water environment for yangcheng lake. J. Water Resour. Water Eng. 2015, 26, 86-90. (In Chinese)

25. Jiang, Y.; Wu, Z.S.; Zhao, Z.H.; Wang, X.L.; Liu, X.; Li, Q.Y.; Cai, Y.J. Spatial distribution and pollution assessment of nitrogen, phosphorus and heavy metals in surface sediments of Lake Yangcheng, Jiangsu Province, China. Res. Environ. Sci. 2016, 29, 1590-1599. (In Chinese)

26. Zhao, L.; Weng, J. Research of Phytoplankton Status in Yangcheng Lake and Evaluation of Its Eutrophication. Adm. Tech. Environ. Monit. 2013, 25, 27-29. (In Chinese)

27. Yang, H.; Chen, J.; Tan, J.H. Analysis of water quality change and pollutant flux of river channels into Yangcheng Lake. Water Res. Prot. 2016, 32, 129-132. (In Chinese)

28. Shen, G.H.; Zhang, R.Q.; Gao, X.P. The trend analysis of water quality change in Lake Yangchenghu. J. Water Resour. Res. 2014, 35, 41-43. (In Chinese)

29. Vollenweider, R.A. Scientific Fundamentals of the Eutrophication of Lakes and Flowing Waters, with Particular Reference to Nitrogen and Phosphorus as Factors in Eutrophication. Technical Report (DAS/CSI/68.27); OECD: Paris, France, 1970.

30. Song, X.H.; Gu, H.D.; Bing, X.W.; Yang, C.G. Correlation of Three Water Quality Parameters-PI, BOD5 and TOC in Yangcheng Lake. Environ. Sci. Technol. 2011, 34, 109-113. (In Chinese)

31. Jørgensen, S.E. A review of recent developments in lake modelling. Ecol. Model. 2010, 221, 689-692. [CrossRef]

32. Jørgensen, S.E. Models as instruments for combination of ecological theory and environmental practice. Ecol. Model. 1994, 75, 5-20. [CrossRef]

33. Zhang, L.; Lin, W.; Li, K.; Sheng, J.; Wei, A.; Luo, F.; Wang, Y.; Wang, X.; Zhang, L. Three-dimensional water quality model based on FVCOM for total load control management in Guan River Estuary, Northern Jiangsu Province. J. Ocean Univ. Chin. 2016, 15, 261-270. [CrossRef]

34. Feng, T.; Wang, C.; Hou, J.; Wang, P.; Liu, Y.; Dai, Q.; Yang, Y.; You, G. Effect of inter-basin water transfer on water quality in an urban lake: A combined water quality index algorithm and biophysical modelling approach. Ecol. Indic. 2017, 92, 61-71. [CrossRef]

35. Yin, Z.; Seo, D. Analysis of optimum grid determination of water quality model with 3-D hydrodynamic model using environmental fluid dynamics code (EFDC). Environ. Eng. Res. 2016, 21, 171-179. [CrossRef]

36. Gong, R.; Xu, L.; Wang, D.G.; Li, H.Y.; Xu, J. Water Quality Modeling for a Typical Urban. Lake Based on the EFDC Model. Environ. Model. Assess. 2016, 21, 643-655. [CrossRef]

37. Wang, Z.; Zou, R.; Zhu, X.; He, B.; Yuan, G.; Zhao, L.; Liu, Y. Predicting lake water quality responses to load reduction: A three-dimensional modeling approach for total maximum daily load. Int. J. Environ. Sci. Technol. 2013, 11, 423-436. [CrossRef]

38. Wu, G.Z.; Xu, Z.X. Prediction of algal blooming using EFDC model: Case study in the Daoxiang Lake. Ecol. Model. 2011, 222, 1245-1252. [CrossRef] 
39. Liu, Y.; Wang, Y.; Hu, S.; Dong, F.; Zou, R.; Zhao, L.; Guo, H.; Zhu, X.; He, B. Quantitative evaluation of lake eutrophication responses under alternative water diversion scenarios: A water quality modeling-based statistical analysis approach. Sci. Total Environ. 2014, 468, 219-227. [CrossRef] [PubMed]

40. Mellios, N.; Kofinas, D.; Laspidou, C.; Papadimitriou, T. Mathematical modeling of trophic state and nutrient flows of Lake Karla using the PCLake model. Environ. Processes 2015, 2, 85-100. [CrossRef]

41. Janse, J.H.; Scheffer, M.; Lijklema, L.; Liere, L.V.; Sloot, J.S.; Mooij, W.M.; Jørgensen, S.E. Estimating the critical phosphorus loading of shallow lakes with the ecosystem model PCLake: Sensitivity, calibration and uncertainty. Ecol. Model. 2010, 221, 654-665. [CrossRef]

42. Akkoyunlu, A.; Karaaslan, Y. Assessment of improvement scenario for water quality in Mogan Lake by using the AQUATOX Model. Environ. Sci. Pollut. Res. 2015, 22, 14349-14357. [CrossRef] [PubMed]

43. Zhu, Y.Q. Application of ecosystem model in studying eutrophication control measures for Dianshan Lake. Environ. Sci. Technol. 2011, 24, 12-18. (In Chinese)

44. Wang, X.D.; Zhang, S.S.; Liu, S.L.; Chen, J.W. A two-dimensional numerical model for eutrophication in Baiyangdian Lake. Front. Environ. Sci. Eng. 2012, 6, 815-824. [CrossRef]

45. Pei, H.; Wang, Y. Eutrophication research of West Lake, Hangzhou, China: Modeling under uncertainty. Water Res. 2003, 37, 416-428.

46. Chen, Q.W.; Zhang, C.C.; Recknagel, F.; Guo, J.; Blanckaert, K. Adaptation and multiple parameter optimization of the simulation model SALMO as prerequisite for scenario analysis on a shallow eutrophic Lake. Ecol. Model. 2014, 273, 109-116. [CrossRef]

47. Hu, W.P.; Zhai, S.J.; Zhu, Z.C.; Han, H.J. Impacts of the Yangtze River water transfer on the restoration of Lake Taihu. Ecol. Eng. 2008, 34, 30-49. [CrossRef]

48. Hu, W.P.; Jørgensen, S.E.; Zhang, F.B. A vertical-compressed three-dimensional ecological model in Lake Taihu, China. Ecol. Model. 2006, 190, 367-398. [CrossRef]

49. Hu, W.P.; Jørgensen, S.E.; Fabing, Z.; Chen, Y.G.; Hu, Z.; Yang, L. A model on the carbon cycling in Lake Taihu, China. Ecol. Model. 2011, 222, 2973-2991.

50. Han, T.; Zhang, H.J.; Hu, W.P.; Deng, J.C.; Li, Q.Q.; Zhu, G. Research on self-purification capacity of Lake Taihu. Environ. Sci. Pollut. Res. 2015, 22, 8201-8215. [CrossRef] [PubMed]

51. Pápista, É.; Ács, É.; Böddi, B. Chlorophyll-a determination with ethanol-A critical test. Hydrobiology 2002, 485, 191-198. [CrossRef]

52. Jin, X.C.; Tu, Q.Y. The Standard Methods for Observation and Analysis in Lake Eutrophication; Chinese Environmental Science Press: Beijing, China, 1990. (In Chinese)

53. Jørgensen, S.E.; De Bernardi, R. The use of structural dynamic models to explain successes and failures of biomanipulation. Hydrobiology 1998, 379, 147-158.

54. Hu, W.P. A review of the models for Lake Taihu and their application in lake environmental management. Ecol. Model. 2016, 319, 9-20. [CrossRef]

55. Zhang, H.J.; Hu, W.P.; Gu, K.; Li, Q.Q.; Zheng, D.L.; Zhai, S.H. An improved ecological model and software for short-term algal bloom forecasting. Environ. Model. Softw. 2013, 48, 152-162. [CrossRef]

56. Li, Q.Q.; Hu, W.P.; Zhai, S.H. Integrative Indicator for Assessing the Alert Levels of Algal Bloom in Lakes: Lake Taihu as a Case Study. J. Environ. Manag. 2015, 57, 237-250. [CrossRef] [PubMed]

57. Zhang, J.J.; Jørgensen, S.E.; Tan, C.O.; Beklioglu, M. A structurally dynamic modelling—Lake Mogan, Turkey as a case study. Ecol. Model. 2003, 164, 103-120. [CrossRef]

58. Kong, X.Z.; Jørgensen, S.E.; He, W.; Qin, N.; Xu, F.L. Predicting the restoration effects by a structural dynamic approach in Lake Chaohu, China. Ecol. Model. 2013, 266, 73-85. [CrossRef]

59. Jørgensen, S.E.; Ray, S.; Berec, L.; Straskraba, M. Improved calibration of a eutrophication model by use of the size variation due to succession. Ecol. Model. 2002, 153, 269-277. [CrossRef]

60. Gui, Z.F.; Xue, B.; Yao, S.C.; Wei, W.J. Water Quality Status and Influencing Factors of Yangcheng Lake, China. Sci. Geogr. Sin. 2011, 31, 1487-1492. (In Chinese)

61. Zou, R.; Zhang, X.; Liu, Y.; Chen, X.; Zhao, L.; Zhu, X.; He, B.; Guo, H. Uncertainty-based analysis on water quality response to water diversions for Lake Chenghai: A multiple-pattern inverse modeling approach. J. Hydrol. 2014, 514, 1-14. [CrossRef]

62. Welch, E.B.; Patmont, C.R. Lake restoration by dilution: Moses lake, Washington. Water Res. 1980, 14, 1317-1325. [CrossRef] 
63. Welch, E.B.; Weiher, E.R. Improvement in Moses Lake quality from dilution and sewage diversion. Lake Reserv. Manag. 1987, 3, 58-65. [CrossRef]

64. Li, Y.; Acharya, K.; Yu, Z. Modeling impacts of Yangtze River water transfer on water ages in Lake Taihu, China. Ecol. Eng. 2011, 37, 325-334. [CrossRef]

65. Mehner, T.; Diekmann, M.; Gonsiorczyk, T.; Kasprzak, P.; Koschel, R.; Krienitz, L.; Rumpf, M.; Schulz, M.; Wauer, G. Rapid Recovery from Eutrophication of a Stratified Lake by Disruption of Internal Nutrient Load. Ecosystem 2008, 11, 1142-1156. [CrossRef]

66. Wichelen, J.V.; Declerck, S.; Muylaert, K.; Hoste, I.; Geenens, V.; Vandekerkhove, J.; Michels, E.; Pauw, N.D.; Hoffmann, M.; Meester, L.D. The importance of drawdown and sediment removal for the restoration of the eutrophied shallow Lake Kraenepoel (Belgium). Hydrobiology 2007, 584, 291-303. [CrossRef]

67. Liu, H.; Benoit, G.; Liu, T.; Liu, Y.; Guo, H. An integrated system dynamics model developed for managing lake water quality at the watershed scale. J. Environ. Manag. 2015, 155, 11-23. [CrossRef] [PubMed]

68. Chen, M.; Ding, S.; Liu, L.; Xu, D.; Han, C.; Zhang, C. Iron-coupled inactivation of phosphorus in sediments by macrozoobenthos (chironomid larvae) bioturbation: Evidences from high-resolution dynamic measurements. Environ. Pollut. 2015, 204, 241-247. [CrossRef] [PubMed]

(C) 2018 by the authors. Licensee MDPI, Basel, Switzerland. This article is an open access article distributed under the terms and conditions of the Creative Commons Attribution (CC BY) license (http:/ / creativecommons.org/licenses/by/4.0/). 